\title{
Implementasi Pendidikan Berasaskan Hasil (PBH) melalui Pembelajaran Berasaskan Projek (PBPj) untuk Menilai Pencapaian Domain Kognitif Berdasarkan Topik Ekosistem Terancam
}

\author{
Nitce Isa Medina Machmudi Isaa ${ }^{a}$ Mai Shihah Abdullah ${ }^{*}$ \\ aSekolah Menengah Kebangsaan (P) Sri Aman, 46100 Petaling Jaya, Selangor \\ bJabatan Biologi, Fakulti Sains dan Matematik, Universiti Pendidikan Sultan Idris,Tanjong Malim, Perak.
}

*Corresponding author: mai.shihah@fsmt.upsi.edu.my

\begin{abstract}
The education system in Malaysia is in the process creating a paradigm shift from implementing an external evaluation to School Based Assessment (SBA). The Malaysia Education Blueprint 2015-2025 (Higher Education) or the MEB (HE) (Ministry of Higher Education, 2015) is formulated based on the vision and aspiration of Malaysia Education Development Plan (2013-2015) and National Higher Education Strategic Plan (Pelan Strategik Pengajian Tinggi Negara (PSPTN)) in educating students who are knowledgeable, skilled and talented to face the challenges of the $21^{\text {st }}$ century. Shift 1 of the blueprint aims to foster graduates who are holistic, balanced and entrepreneurial in line with the National Education Philosophy. This footstep is closely applied by the Ministry of Education to develop the holistic student profile in the schools. A new evaluation combines the three domains of cognitive, affective and psychomotor instead of focusing on the cognitive domain (DC) those are taken into account in determining student's achievement. This study was conducted to identify the impact on assessment using Outcome Based Education (OBE) through the application of project-based learning (PjBL) by comparing it with the current academic achievement ranking using DC only. All domains involved were represented by academic (cognitive domain), social skills (affective domain) and manipulative skills (psychomotor domain). This study also take into account to determine the impact of students' assessment in the cognitive domain using Outcome-based Education (OBE) through the application of Project-based Learning (PjBL) compared to Traditional Learning (TL) in the topic of 'Threatened Ecosystem.' This study is a quantitative research using quasi-experimental design. A total of 30 Form 4 science stream students were selected using purposive sampling. This study demonstrated that there is no significant difference between the traditional learning (TL) and project-based learning (PJBL) to evaluate students' cognitive domain. Assessment outlined in the Outcome-based Education is a good evaluation method to be applied to the secondary Based on these findings it is proposed evaluation in OBE through PjBL method is of a better assessment tool to be applied to secondary school, preferably the science stream students. This enables them to be evaluated in a more holistic manner which is in line with the full implementation of PBS in the near future. Subsequently, students' achievement in affective and psychomotor domains should be carried out to oversee the effect onto the holistic evaluation as outlined in OBE.
\end{abstract}

Keywords: Project-based learning (PjBL); outcome-based education (OBE); school-based assessment (SBA); threatened ecosystem

\begin{abstract}
Abstrak
Sistem pendidikan di Malaysia sedang dalam proses membuat anjakan paradigma daripada melaksanakan penilaian secara eksternal kepada Penilaian Berasaskan Sekolah (PBS). Pelan Pembangunan Pendidikan Malaysia 2015-2025 (Pendidikan Tinggi) atau PPPM (PT) (Kementerian Pendidikan Malaysia, 2015) dirangka berasaskan wawasan dan aspirasi PPPM (2013-2025) dan PSPTN dalam mendidik pelajar yang berbakat, berkemahiran dan berilmu yang bersedia menghadapi cabaran abad ke-21. Lonjakan 1 PPPM (PT) bertujuan membentuk graduan yang holistik, seimbang dan berciri keusahawanan sejajar dengan Falsafah Pendidikan Negara (FPN). Salah satu daripada inisiatif Lonjakan 1 ialah pelaksanaan Sistem Penilaian Bersepadu yang menzahirkan pencapaian holistik pelajar hasil daripada pengalaman pembelajaran di IPT. Langkah yang sama digunakan oleh Kementerian Pendidikan Malaysia untuk menggubal profil pelajar holistik di sekolah-sekolah. Penilaian yang menggabungkan ketiga-tiga domain kognitif, afektif dan psikomotor ini dipraktis dalam Pendidikan Berasaskan Hasil (PBH) berbanding hanya domain kognitif (DK) yang diambil kira bagi menentukan pencapaian pelajar sebagaimana yang dipraktiskan dalam penilaian pada masa kini. Kajian ini dijalankan untuk mengenal pasti kesan ke atas penilaian pelajar dalam DK yang menggunakan kaedah Pendidikan Berasaskan Hasil (PBH) melalui aplikasi Pembelajaran Berasaskan Projek (PBPj) dengan membandingkannya dengan Pembelajaran Trasional (PT) bagi topik 'Ekosistem Terancam.' Kajian ini merupakan kajian kuantitatif menggunakan reka bentuk eksperimen kuasi. Seramai 60 orang pelajar aliran sains Tingkatan 4 dipilih dengan menggunakan pensampelan bertujuan dengan 30 orang bagi setiap kumpulan kawalan (pengajaran tradisional) dan kumpulan rawatan (pembelajaran berasaskan projek). Dapatan kajian ini menunjukkan tidak ada perbezaan yang signifikan di antara pembelajaran berasaskan projek (PBPj) dengan Pembelajaran Tradisional untuk menilai domain kognitif pelajar. Kajian ini mencadangkan penilaian dalam PBH adalah kaedah pentaksiran yang sesuai untuk diaplikasikan kepada pelajar sekolah menengah terutamanya pelajar aliran sains dengan pelbagai pendekatan pembelajaran dan pengajaran. Ini membolehkan mereka dinilai dengan lebih holistik selari dengan pelaksanaan PBS sepenuhnya dalam masa yang terdekat. Seterusnya, pencapaian pelajar dalam domain-domain afektif dan psikomotor perlu dijalankan untuk mendapatkan kesan yang menyeluruh ke atas penilaian holistik yang digariskan oleh $\mathrm{PBH}$ ini.
\end{abstract}

Kata kunci: Pembelajaran berasaskan projek (PBPj); pembelajaran berasaskan hasil (PBH); penilaian berasaskan sekolah (PBS); ekosistem terancam 


\subsection{PENGENALAN}

Pelan Pembangunan Pendidikan Malaysia 2015-2025 (Pendidikan Tinggi) atau PPPM (PT) (Kementerian Pendidikan Malaysia, 2015) dirangka berasaskan wawasan dan aspirasi PPPM (2013-2025) dan PSPTN dalam mendidik pelajar yang berbakat, berkemahiran dan berilmu yang bersedia menghadapi cabaran abad ke-21. Lonjakan 1 PPPM (PT) bertujuan membentuk graduan yang holistik, seimbang dan berciri keusahawanan sejajar dengan Falsafah Pendidikan Negara (FPN). Salah satu daripada inisiatif Lonjakan 1 ialah pelaksanaan Sistem Penilaian Bersepadu yang menzahirkan pencapaian holistik pelajar hasil daripada pengalaman pembelajaran di IPT. PNGK Bersepadu (iCGPA) berperanan untuk memacu amalan penjajaran konstruktif bagi memastikan reka bentuk kurikulum, pelaksanaan kurikulum dan proses pentaksiran pada peringkat kursus/mata pelajaran dan program/peringkat persekolahan adalah berkualiti (Rajah 1).

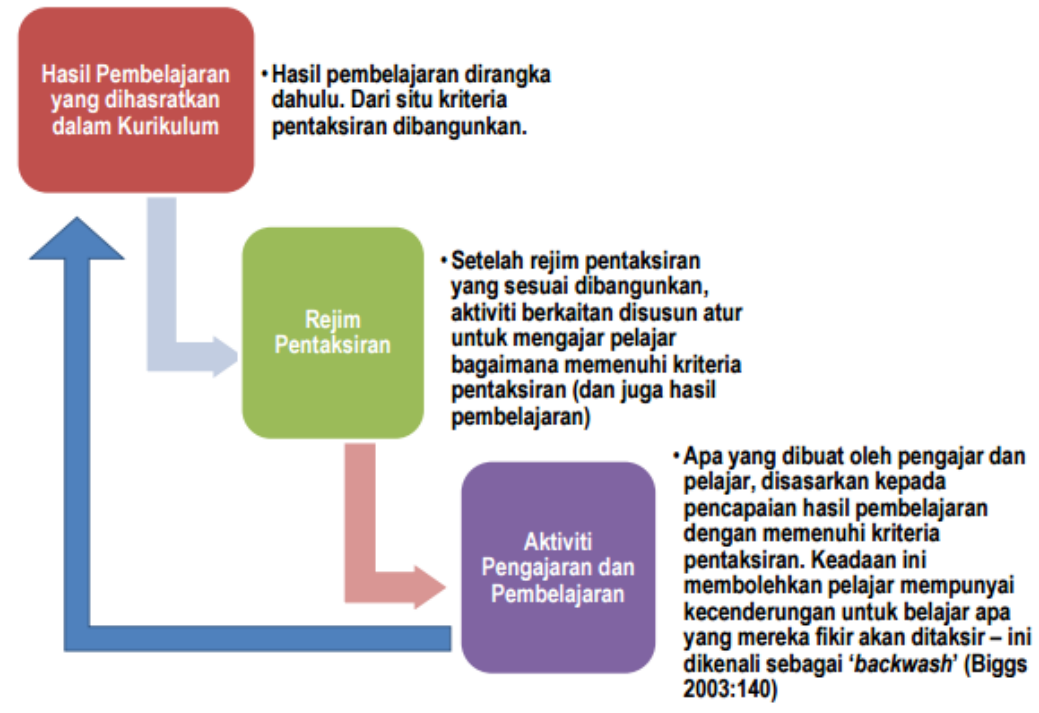

Rajah 1 Model penjajaran konstruktif oleh biggs

Sistem pendidikan yang baik tidak harus tertumpu kepada domain kognitif (DK) sahaja tetapi mesti mengambil kira sikap dan kemahiran pelajar untuk memastikan ia memberi kejayaan jangka panjang kepada mereka. Komponen pengajaran dan pembelajaran selain penilaian di sekolah melibatkan tiga domain iaitu DK, domain afektif (DA) dan domain psikomotor (DP). Apa yang terjadi pada penerapannya sistem pendidikan masa kini yang lebih berorientasi pada pengembangan kecerdasan intelektual (IQ) (Domain Kognitif) sahaja dan dimensi kecerdasan yang lain seperti kecerdasan emosional (EQ) dan kecerdasan spiritual (SQ) (kedua-duanya domain afektif) serta kecerdasan kemahiran psikomotor (domain psikomotor) dipinggirkan.

Dalam sukatan pelajaran mata pelajaran biologi Tingkatan 4 telah disenaraikan semua hasil pembelajaran (HP) yang perlu dicapai oleh pelajar merangkumi kesemua domain kognitif, afektif dan psikomotor (Pusat Perkembangan Kurikulum, 2006). Namun begitu, tuntutan peperiksaan awam dalam sistem pendidikan menyebabkan kebanyakan guru hanya mengambil kira pencapaian akademik pelajar yang berkaitan dengan DK dan kurang memberikan tumpuan kepada DA dan DP yang juga penting untuk dikuasai pelajar walaupun dengan pelbagai kekangan seperti masa dan infrastruktur. Rangkuman faktor-faktor seperti ini turut mengehadkan guru untuk memberi tumpuan dalam pencapaian hasil pembelajaran pelajar apatah lagi mengambil kira domain-domain selain daripada DK bagi mengukur pencapaian akademik mereka.

\section{Kerangka Konseptual Kajian}

Kerangka kerja konseptual sebagaimana yang dikehendaki dalam Pembelajaran Berasaskan Hasil (PBH) mempunyai perkaitan antara Falsafah Pendidikan Negara yang menyenaraikan hasrat untuk memoptimumkan potensi jasmani, emosi, rohani dan intelek seorang pelajar. Ini boleh dicapai dengan membuat penjajaran konstruktif kepada matlamat dan objektif yang terkandung dalam Kurikulum Bersepadu Sekolah Menengah setiap mata pelajaran yang diambil oleh pelajar. Seterusnya setiap matlamat ini perlu dijajarkan kepada hasil pembelajaran modul yang terkandung dalam setiap mata pelajaran. Penjajaran konstruktif ini menjadi tonggak tanpa mengira kepelbagaian kaedah pengajaran yang dilaksanakan. Strategi penilaian yang sesuai turut dijajarkan untuk menilai pencapaian setiap hasil pembelajaran. Strategi penilaian yang diamalkan merangkumi ketiga-tiga domain (kognitif, afektif dan psikomotor) dan boleh ditambah nilai dengan memasukkan penilaian kemahiran insaniah.

Sebagai contoh kerangka kerja konseptual PBH kajian ini (Rajah 2), mempamerkan hasil pembelajaran dalam modul Ekosistem Terancam telah dijajarkan kepada objektif pembelajaran mata pelajaran Biologi. Strategi pengajaran dan pembelajaran yang dilaksanakan ialah Pembelajaran Berasaskan Projek (PBPj). Pencapaian akademik diambil kira untuk skor DK, kemahiran sosial untuk skor DA dan kemahiran manipulatif untuk skor DP. Hasil kesepaduan kesemua aspek yang diambil kira adalah diharapkan dapat menghasilkan satu gred prestasi holistik pelajar. 


\title{
Pendidikan Berasaskan Hasil (PBH)
}

\author{
Falsafah Pendidikan Negara
}

$\widehat{\bigcup ~ D i s o k o n g ~ o l e h ~}$

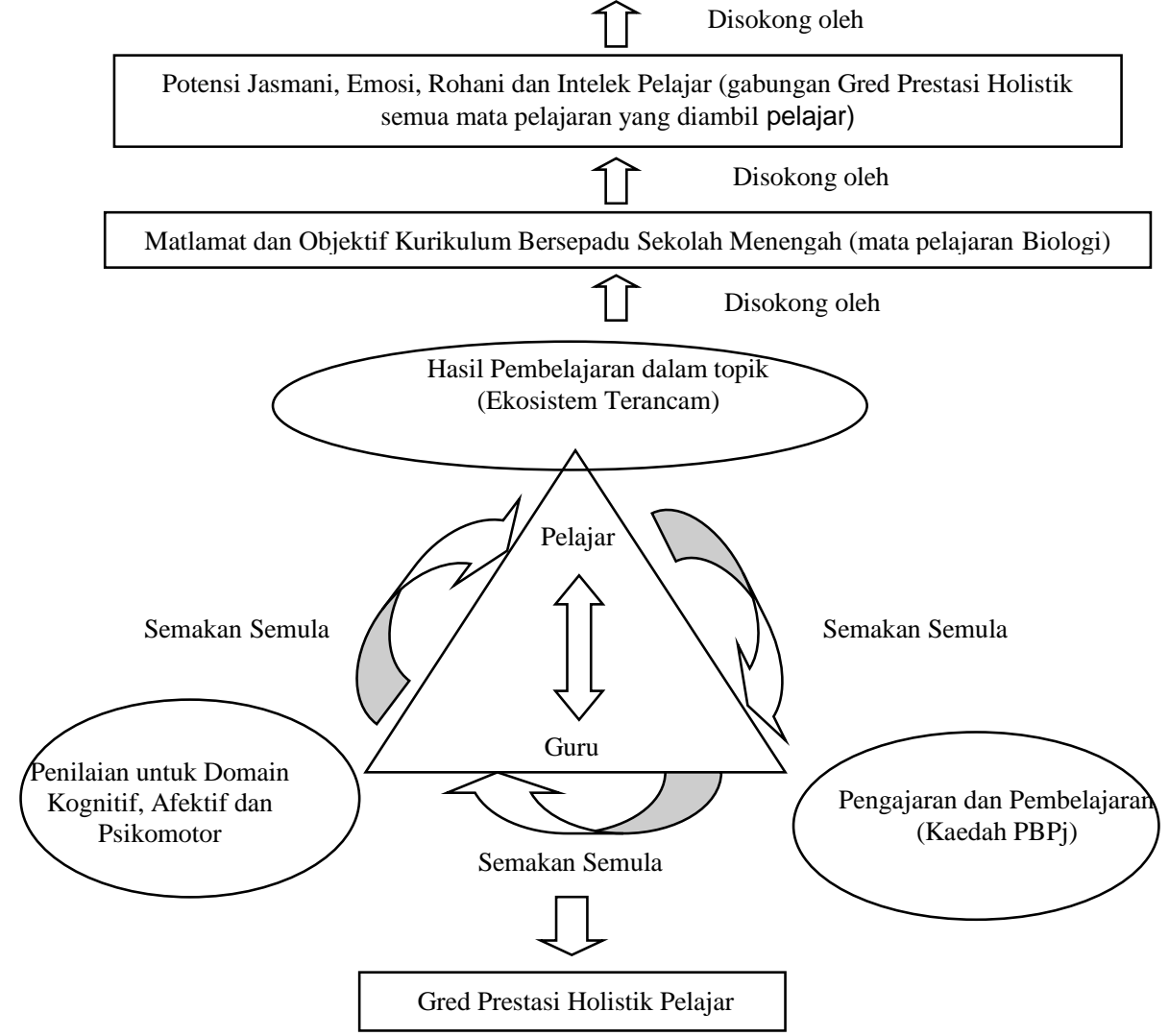

Rajah 2 Kerangka Konsep Hubungan Pembelajaran Berasaskan Hasil (PBH), Pembelajaran Berasaskan Projek (PBPj) dan Penilaian Domain Pembelajaran (Kognitif, Afektif dan Psikomotor) untuk menghasilkan Gred Prestasi Holistik Pelajar

Pembelajaran Berasaskan Hasil (PBH) menggariskan keperluan untuk pelajar menguasai kesemua HP seperti yang telah disenaraikan dalam kurikulum itu sendiri. Namun begitu, dalam proses melengkapkan langkah-langkah yang telah dirancang, akan terdapat kekurangan dan kelemahan dalam mana-mana komponen. Maka tindakan yang diambil melalui aktiviti semakan semula atau langkah pembetulan adalah usaha secara berterusan untuk meningkatkan prestasi pencapaian HP pelajar untuk sub modul kepada modul kepada mata pelajaran sehinggalah ke prestasi keseluruhannya dari semasa kesemasa. Sekiranya kesemua langkah ini dipatuhi, profil pelajar merangkumi prestasi intelek, rohani, jasmani dan emosi dapat digubal dan boleh dirujuk oleh pembekal pendidikan tinggi (Kolej Vokasional, Kolej Komuniti, Politeknik, Universiti Awam dan Universiti Swasta) untuk kriteria kelayakan masuk dalam program yang sesuai. Seterusnya ia bersinambungan dengan mekanisme yang sama (i-CGPA) yang telah diamalkan di peringkat pengajian tinggi ini boleh dijadikan rujukan kepada bakal majikan untuk memastikan kebolehkerjaan individu dalam pasaran.

\section{Kerangka Kerja Teoretikal}

Kerangka kerja teoretikal ini menerangkan tentang hubungan teori kepada kaedah PBPj, penilaian dalam PBH dan bagaimana penggubalan gred prestasi holistik pelajar kajian ini. Dalam hal ini, faktor tambahan gaya pembelajaran pelajar juga turut dimasukkan sebagai satu faktor penyumbang kepada kesan aplikasi kaedah PBPJ melalui penilaian mengikut kaedah PBH. Rajah 3 menunjukkan perkaitan antara penilaian dalam PBH dan kaedah PBPj dalam kajian ini.

Berdasarkan teori konstruktivisme, kaedah PBPj diperkenalkan sebagai salah satu kaedah P dan P. Gaya pembelajaran pelajar dijadikan faktor sampingan yang dianggap turut memberi kesan kepada implementasi kaedah PBPj. Penilaian mengikut kaedah PBH yang menyatakan keperluan menilai tiga domain iaitu DK, DA dan DP dikhususkan hanya kepada menilai pencapaian akademik (DK), kemahiran sosial (DA) dan kemahiran manipulatif (DP) pelajar dalam kajian. Ketiga-tiga penilaian domain ini dicapai menerusi aplikasi kaedah PBPj dalam kumpulan rawatan, manakala Pengajaran Tradisional (PT) diajar untuk kumpulan kawalan. Kesemua penilaian diperoleh menggunakan instrumen ujian pra, ujian pasca dan rubrik. Modul yang digunakan ialah 'Ekosistem Terancam' yang terkandung instruksi pengajaran dan pembelajaran serta instrumen penilaian untuk ketiga-tiga domain. 


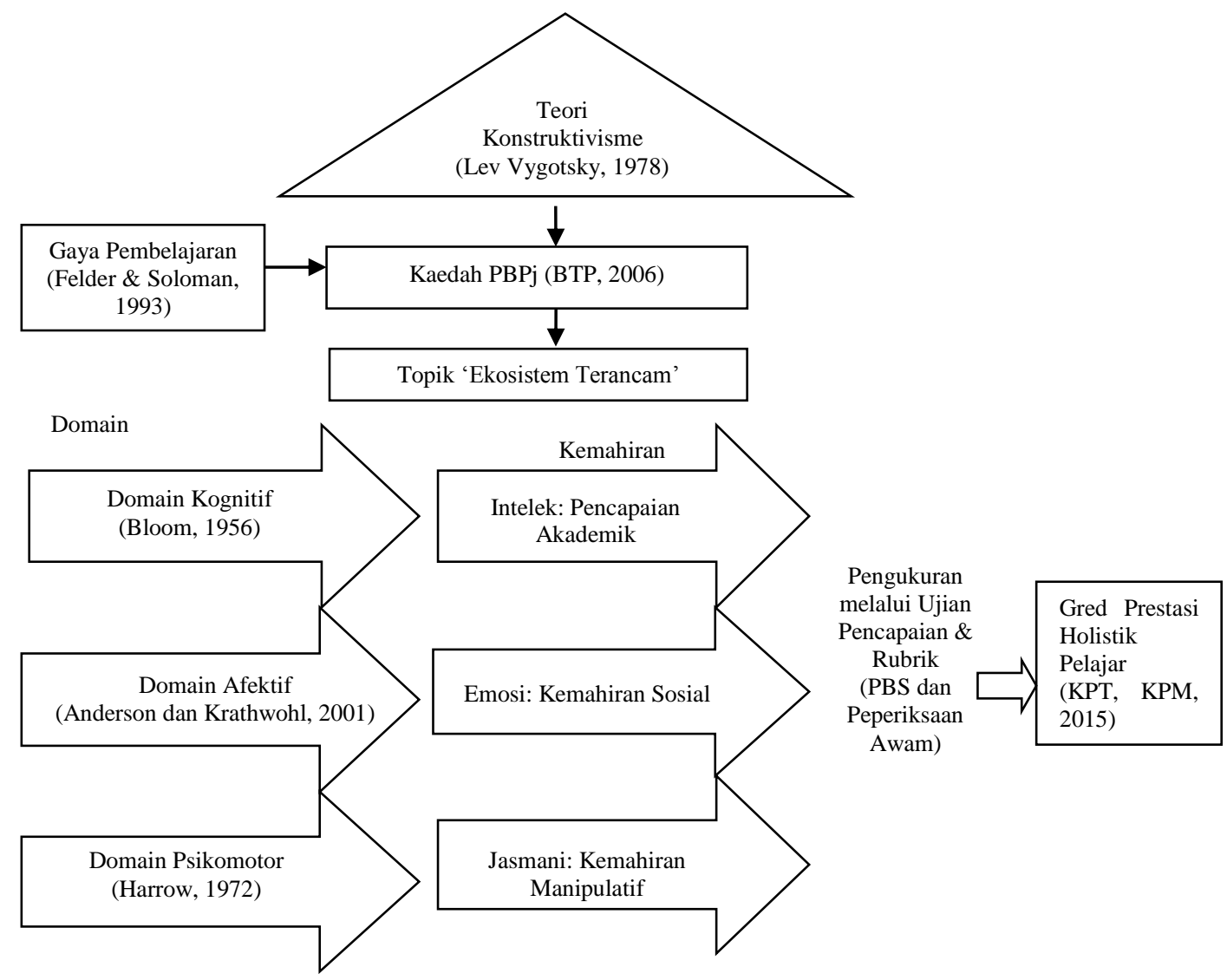

Rajah 3 Kerangka Teori Hubungan Pembelajaran Berasaskan Hasil (PBH), Pembelajaran Berasaskan Projek (PBPj) dan Penilaian Domain Pembelajaran (Kognitif, Afektif dan Psikomotor) untuk menghasikan Gred Prestasi Holistik Pelajar

Domain-domain yang diusulkan oleh para ilmuwan dalam kajian ini adalah seperti yang dicadangkan oleh Bloom (1956), Anderson \& Krathwohl (2001) dan Harrow (1972). Kaedah PBPj yang digunakan dalam kajian ini adalah seperti yang dicadangkan oleh pihak BTP (2006). Penilaian ketiga-tiga domain ini boleh diukur iaitu pencapaian akademik, kemahiran sosial dan kemahiran manipulatif yang dipantau untuk kedua-dua penilaian formatif (PBS) dan sumatif (peperiksaan awam) membawa kepada penggabungan (kumulatif) gred yang boleh menunjukkan tahap pencapaian keseluruhan pelajar menerusi penilaian dalam PBH. Maka, penilaian setiap pelajar dalam kumpulan kaedah PBPj dibuat berdasarkan skor terkumpul untuk ketiga-tiga domain, dan bukan tertumpu pada hanya satu domain kognitif sahaja sebagaimana yang diamalkan pada masa kini. Pentaksiran seperti ini adalah mengikut yang disarankan oleh KPM dan KPT dan dalam konteks kajian ini ia dinamakan Prestasi Gred Holistik Pelajar. Kaedah pengajaran dan pembelajaran yang dirancang dalam rancangan instruksi pengajaran sesuatu modul mesti mengambil kira penjajaran yang bertepatan dengan objektif pembelajaran, hasil pembelajaran dan pentaksiran yang dijalankan untuk ketiga-tiga domain pembelajaran kognitif, afektif dan psikomotor. Kemahiran insaniah juga turut boleh dimasukkan dalam pembinaan profil gred prestasi holistik yang diaspirasikan.

Kajian ini hanya memfokuskan kepada pencapaian domain pembelajaran kognitif dengan membandingkan pelaksanaan PBPj dan Pengajaran Tradisional menggunakan pendekatan PBH yang memerlukan penjajaran konstruktif dibuat ke atas objektif pembelajaran, hasil pembelajaran kepada pentaksiran.

\section{Objektif Kajian}

Objektif yang ingin dicapai dalam kajian ini adalah membandingkan kesan pencapaian domain kognitif yang menggunakan modul PBPj dengan Pengajaran Tradisional dengan pendekatan $\mathrm{PBH}$.

\section{Hipotesis Kajian}

Hipotesis kajian dinyatakan seperti berikut:

$\mathrm{H}_{0}$ : Tidak terdapat perbezaan yang signifikan bagi skor min ujian pra dan ujian pasca bagi kumpulan kaedah PT.

$\mathrm{H}_{02}$ : Tidak terdapat perbezaan yang signifikan bagi skor min ujian pra dan ujian pasca bagi kumpulan kaedah PBPj.

$\mathrm{H}_{0}$ : Tidak terdapat perbezaan yang signifikan bagi skor min ujian pasca antara kumpulan kaedah PBPj dan kumpulan kaedah PT.

$\mathrm{H}_{0} 4$ : Tidak terdapat perbezaan yang signifikan bagi pencapaian domain kognitif pelajar yang menggunakan kaedah PBPj dengan PT. 


\subsection{SOROTAN LITERATUR}

\section{Rasional Anjakan Instrumen Penilaian}

Beberapa kajian menunjukkan penilaian yang digunakan seharusnya dapat menilai prestasi sebenar pelajar secara tepat. Kajian oleh Rosadah et al. (2005) memperincikan mekanisme dan proses penilaian domain kognitif secara khusus dalam kalangan pelajar pintar cerdas akademik. Dapatan mereka menunjukkan dalam kalangan pelajar pintar cerdas akademik ini mempamerkan dua jenis prototaip pemprosesan kognitif seperti perhatian dan berturutan yang tinggi. Namun prestasi mereka rendah dalam perancangan dan proses. Kajian pengaruh sikap rakan sebaya (sebahagian daripada elemen sosialisasi dalam domain afektif) dalam kalangan pelajar prestasi cerdas akademik (Mohd Zuri Ghani et al., 2010.) menunjukkan interaksi dan sumbangan rakan sebaya dan kestabilan emosi (Mohd Zuri Ghani et $a l ., 2010)$ mempengaruhi pelajar sekolah harian berbanding pelajar pintar cerdas akademik dalam pencapaian akademik sebenar mereka.

Kajian mereka menunjukkan pelajar sekolah harian yang merupakan kumpulan majoriti dalam sistem pendidikan di Malaysia adalah lebih berisiko jika penilaian akademik mereka hanya disandarkan kepada domain kognitif sahaja. Umumnya, setiap individu yang dilahirkan sememangnya mempunyai potensi dan bakat yang secara genetiknya boleh dikembang dan ditingkatkan bukan hanya dengan mendedahkannya kepada persekitaran proses pembelajaran dan pembelajaran yang kondusif, malahan perlu dijajarkan kepada hasil pembelajaran yang dingini dengan melaksanakan instrumen penilaian yang komprehensif bagi memperoleh potensi pelajar yang sebenar yang menggabungkan ketiga-tiga domain afektif, psikomotor dan kognitif.

\section{Strategi Pengajaran dan Pembelajaran}

Terdapat pelbagai kaedah penilaian dan pendekatan pengajaran yang digunakan dalam proses pengajaran dan pembelajaran yang diaplikasikan oleh tenaga pengajar. Dalam kajian ini kaedah penilaian dalam Pembelajaran Berasaskan Hasil (PBH) dan pendekatan Pembelajaran Berasaskan Projek (PBPj) digunakan yang selari dengan penjajaran konstruktif yang digariskan dalam Pelan Pembangunan Pendidikan Malaysia 2015-2025 (Pendidikan Tinggi) atau PPPM (PT) (Kementerian Pendidikan Tinggi Malaysia, 2015).

\section{Pembelajaran Berasaskan Hasil (PBH)}

Kaedah penilaian yang digariskan dalam Pembelajaran Berasaskan Hasil (PBH) atau Outcome Based Education (OBE) merupakan satu pendekatan untuk menilai keberkesanan HP pelajar. Pendekatan ini baru diperkenalkan di Malaysia (Jaafar et al., 2008), walaupun telah lama diamalkan sejak tahun 1980an dan 1990an di negara-negara lain seperti Amerika Syarikat, United Kingdom dan Australia (Killen, 2000). Menurut Butler (2004) dan Killen (2000), terdapat empat prinsip asas pendekatan PBH yang akan menentukan kejayaan guru dan pelajar iaitu: i) fokus yang jelas; ii) merekabentuk semula; iii) jangkaan yang tinggi dan iv) peluang yang terbuka.

Fokus yang jelas akan membantu pembinaan, pelaksanaan dan penilaian kurikulum yang diasaskan daripada HP yang sepatutnya dipamerkan oleh pelajar. Merekabentuk semula merujuk kepada rangka kurikulum dan aktiviti pendidikan yang disediakan secara 'berpatah balik ke belakang' di mana HP yang dijangka perlu ditetapkan terlebih dahulu. Setelah HP yang berkenaan ditetapkan, maka barulah proses pengajaran dan pembelajaran (P dan P), bahan bantu mengajar dan penilaian dirangka mengikut acuan HP yang ditetapkan tadi. Prinsip yang ketiga iaitu jangkaan tinggi yang sepatutnya diletakkan oleh guru terhadap semua pelajarnya. Prinsip yang terakhir iaitu peluang yang luas berkait rapat dengan prinsip yang ketiga. Prinsip yang terakhir ini adalah berasaskan kepada pandangan bahawa bukan semua pelajar berupaya belajar perkara yang sama melalui kaedah yang sama dan pada masa yang sama. Pelajar mempunyai peluang yang berterusan untuk menunjukkan pencapaian terbaik bagi menguasai HP mereka.

Berbeza dengan situasi penilaian semasa, penilaian PBH memberi peluang dan menekankan penilaian seseorang pelajar itu menggunakan ketiga-tiga domain DK, DA dan DP (Mohd Ghazali et al., 2008; Md. Baharuddin et al., 2011). Perkara ini sebenarnya telah dijelaskan melalui penekanan objektif pembelajaran (OP) yang tersenarai dalam HP yang sepatutnya dijadikan panduan oleh setiap guru. Guru diberi kebebasan untuk menggunakan strategi yang pelbagai bagi memastikan pelajar mencapai setiap HP yang disenaraikan dalam OP. Pengkaji-pengkaji seperti Roslan \& Mokhtar (2009) dan Md. Baharuddin et al.(2011) menyatakan bahawa antara kaedah P dan P yang boleh digunakan bagi penilaian PBH ialah Pembelajaran Berasaskan Projek (PBPj). Kedua-dua OP dan HP dirangka untuk memudahkan penilaian dijalankan ke atas kefahaman pelajar terhadap kandungan ilmu.

\section{Pembelajaran Berasaskan Projek (PBPj)}

PBPj telah dibuktikan dapat meningkatkan tahap motivasi dan pencapaian akademik pelajar yang terlibat (Yamzon, 1999; Turner \& Grizzaffi, 2003; Brodi, 2008; Yalcin et al., 2009; Bas, 2010; Bell, 2010; Kamaruzaman \&Khairul, 2010; Kaldi et al., 2011). Ini ditunjukkan melalui peningkatan pencapaian akademik pelajar yang berbeza secara signifikan berbanding menggunakan kaedah pembelajaran sedia ada. Bell (2010) menyatakan dalam proses pencarian mencari maklumat tentang projek, mereka akan meningkatkan usaha untuk membaca lebih banyak bahan berkaitan dengan harapan untuk memahami dan belajar melalui PBPj.

Siti Fatimah et al., (2006), Zimmerman (2010) dan Kaldi et al. (2011) menyatakan bahawa PBPj dapat membantu pelajar mempelajari kemahiran-kemahiran sosial dan menyediakan mereka untuk berkolaborasi dengan rakan, bekerja dalam kumpulan, menyediakan pembentangan, berkomunikasi, menganalisis dan memberi sebab. Kemahiran sosial melalui pembelajaran menggunakan PBPj terbentuk melalui aktiviti berkumpulan yang diwujudkan semasa pelajar menyiapkan projek dan belajar menguruskan aktiviti dan mensintesiskan maklumat selain berusaha untuk menyiapkan projek mengikut masa yang ditetapkan (Blumenfeld et al., 1991; Chin \& Chia, 2006; Kamaruzaman \& Khairul, 2010, Papanikalou \& Boubouka, 2010; Kaldi et al., 2011).

Beberapa orang pengkaji sebelum ini turut mengkaji perkaitan antara kemahiran saintifik secara umumnya dengan PBPj seperti yang dilakukan oleh Chan Lin (2008), Yalcin et al. (2009) dan Mookdaporn \& Prasart (2010). Chan Lin (2008) yang menjalankan kajian PBPj atas sekumpulan pelajar yang berusia 10 hingga 11 tahun yang terlibat dalam khemah Sains SciCamp di Taiwan menyatakan pelajar kajiannya menunjukkan peningkatan dari segi memperoleh akses dan melibatkan diri dalam eksperimen saintifik, selain memperoleh 
kemahiran konseptual tentang pemerhatian saintifik. Kemahiran ini jelas dicapai semasa pelajar melakukan pensampelan air sungai untuk menguji kadar kualitinya. Kajian oleh Yalcin et al. (2009) pula menunjukkan bahawa terdapat perbezaan yang signifikan antara kumpulan rawatan dan kumpulan kawalan daripada segi sikap pelajar terhadap mata pelajaran fizik, pencapaian sub bidang elektrik dan kemahiran proses sains. Kajian juga mendapati bahawa memperkayakan pembelajaran di samping membantu memperbaiki sikap mereka terhadap mata pelajaran itu. Kajian yang dijalankan oleh Mookdaporn \& Prasart (2010) membezakan aspek pencapaian akademik, kemahiran manipulatif dan kemahiran analitis antara kumpulan PBPj dan kumpulan kaedah inkuiri. Dapatan kajian menunjukkan terdapat kesan yang positif ditunjukkan terhadap ketiga-tiga aspek bagi kedua-dua kumpulan, namun tiada perbezaan signifikan ditunjukkan jika perbandingan dibuat terhadap kedua-dua kumpulan.

\subsection{METODOLOGI KAJIAN}

Kajian kuantitatif dengan reka bentuk kuasi eksperimental digunakan kerana pengagihan rawak tidak dapat dijalankan sebagaimana yang disarankan oleh beberapa orang pengkaji seperti Plutchik, (1983); Cook \& Campbell, (2006) dan Martin, (2008). Hal ini disebabkan oleh kekangan untuk memenuhi kehendak pihak pentadbiran sekolah yang terikat dengan jadual waktu dan kelas sedia ada. Pemboleh ubah bersandar yang digunakan dalam kajian ini ialah kaedah pengajaran dan pembelajaran; PT dan PBPj, manakala pemboleh ubah tidak bersandar ialah pencapaian pelajaran dalam domain kognitif. Ujian bertulis bagi mengukur pencapaian akademik (DK) dijalankan sebelum kaedah PT dan PBPj dilaksanakan (ujian pra) dan selepas kaedah PT dan PBPj dijalankan (ujian pasca).

Teknik pensampelan purposive yang tersenarai di bawah kategori pensampelan bukan rawak dipilih kerana pelajar yang terlibat dalam kajian ini memenuhi keperluan kajian dan mempunyai ciri-ciri tertentu yang telah ditetapkan (Fraenkel \& Wallen, 1996; Cohen, Manion \& Morrison, 2001; Noraini, 2010). Semua 60 orang pelajar yang dipilih merupakan pelajar-pelajar perempuan Tingkatan 4 yang mengambil mata pelajaran biologi dan dibahagikan kepada kumpulan kawalan (PT) dan kumpulan rawatan (PBPj). Kumpulan PT mengikuti topik ekosistem dengan pengajaran dan pembelajaran tradisional manakala kumpulan PBPj menggunakan modul yang dibangunkan. Pemilihan satu jantina sahaja iaitu perempuan dalam sampel kajian adalah berdasarkan kepada kajian-kajian lepas kerana kecenderungan mereka untuk menggemari mata pelajaran biologi dan lebih mahir menggunakan alatan dan bahan berbanding pelajar lelaki (Christidou, 2006; Miller, Blessing \& Schwartz, 2006).Sekolah yang dipilih juga merupakan sekolah menengah harian yang terletak dalam kawasan bandar di negeri Selangor serta memperoleh taraf sekolah bestari perdana.

\section{Prosedur Kajian}

Kumpulan kawalan diajar topik Ekosistem Terancam ini dengan menggunakan rancangan instruksi kaedah PT. Bagi kumpulan PBPj, pelajar dibahagikan mengikut kumpulan-kumpulan kecil untuk membolehkan kerjasama dijalankan semasa membuat artifak. Dua jenis artifak yang perlu disiapkan oleh mereka ialah brosur dan poster. Langkah-langkah yang dilaksanakan pelajar ialah menetapkan tema penyiasatan, membuat perancangan, membuat penjadualan, pemerhatian dan pemantauan, membuat penilaian untuk menyediakan artifak dan membuat pembentangan. Seterusnya aktiviti di akhir sesi PBPj ialah penilaian keseluruhan termasuk refleksi. Kedua-dua proses pengajaran dan pembelajaran dikendalikan oleh penyelidik.

\subsection{DAPATAN KAJIAN}

Pencapaian akademik diukur menggunakan ujian pra dan ujian pasca. Sebagai perbandingan kedua-dua kumpulan kaedah PBPj dan kaedah PT, ujian-t telah digunakan. Untuk membolehkan ujian-t (salah satu ujian parametrik) dijalankan, normaliti data bagi ujian pra telah diuji terlebih dahulu dan dipaparkan pada Jadual 1.

Jadual 1 Ujian normaliti data bagi ujian pra kumpulan kaedah PBPJ dan kaedah PT

\begin{tabular}{ccccc}
\hline & \multicolumn{2}{c}{ Kaedah PBPj } & \multicolumn{2}{c}{ Kaedah PT } \\
\hline \multirow{2}{*}{ Ujian Pra } & Bilangan & Aras signifikan & Bilangan & Aras signifikan \\
& 30 & .11 & 30 & .69 \\
Ujian Pasca & 30 & .16 & 30 & .02 \\
\hline
\end{tabular}

Untuk memastikan kesemua data yang ada boleh digunakan, ujian boxplot telah dijalankan. Rajah 4 menunjukkan data ujian pra bagi semua sampel kumpulan kaedah PBPJ dan kumpulan kaedah PT, manakala Rajah 5 menunjukkan data ujian pasca bagi semua sampel kedua-dua kumpulan. Ujian ini digunakan untuk mengesan 'outliers data'. 'Outliers data' adalah merupakan situasi apabila sesuatu skor data itu adalah sangat berbeza dibandingkan dengan skor-skor data yang lain, sama ada nilainya terlalu tinggi atau terlalu rendah (Pallant, 2005). Melalui ujian ini didapati tiada data yang dianggap sebagai 'outliers data' maka semua data dari 60 orang sampel telah digunakan untuk dianalisis dan tiada satu pun yang disingkirkan. 

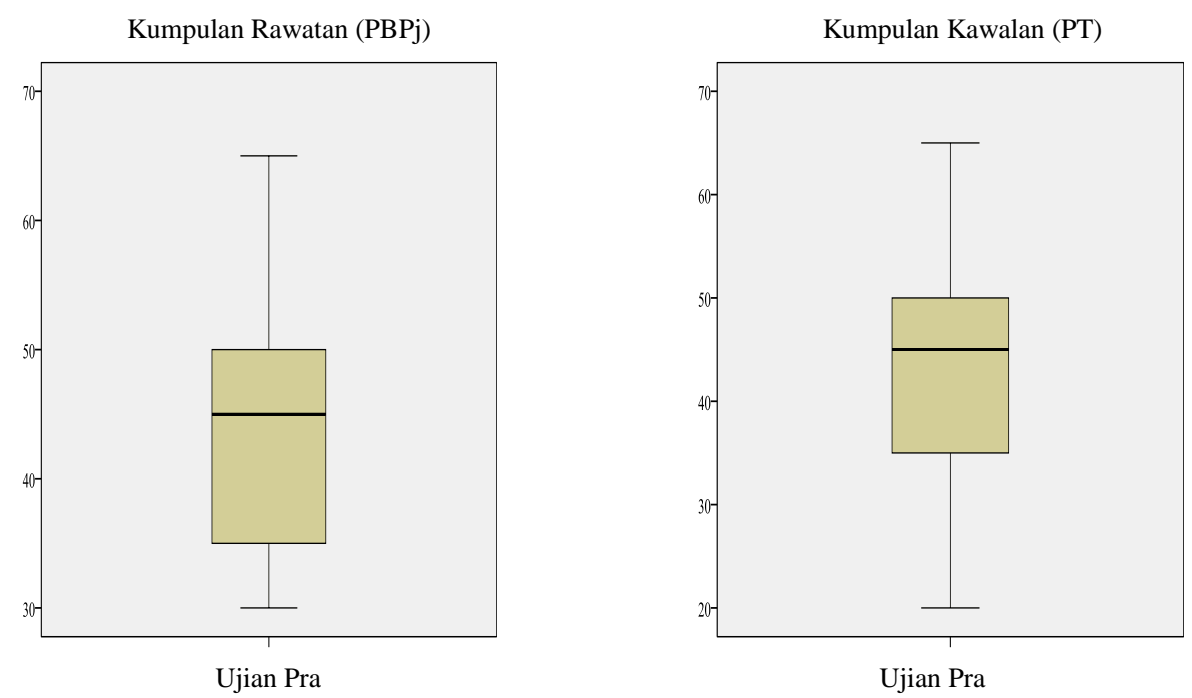

Ujian Pra

Rajah 4 Ujian boxplot bagi data ujian pra

Kumpulan Rawatan (PBPj)

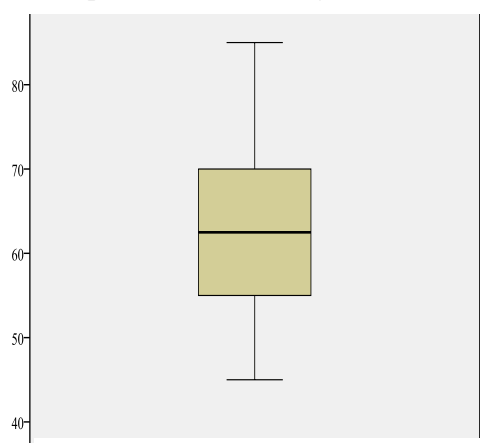

Ujian Pasca

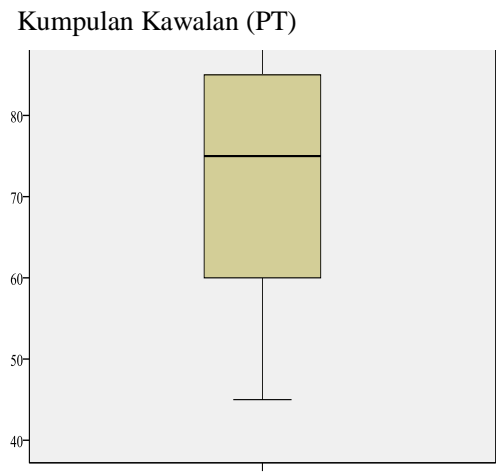

Ujian Pasca

Rajah 5 Ujian boxplot bagi data ujian pasca

Markah permulaan bagi kedua-dua kumpulan dipastikan setara melalui ujian pra yang diberikan. Ini adalah untuk memastikan bahawa semua sampel dari kedua-dua kumpulan adalah homogen. Semua skor telah dikumpul dan min skor bagi kedua-dua kumpulan dibandingkan. Hipotesis pertama yang diuji dalam kajian ini adalah seperti berikut:

$\mathrm{H}_{0}$ : $\quad$ Tidak terdapat perbezaan yang signifikan bagi skor min ujian pra antara kumpulan kaedah PBPj dan kumpulan kaedah PT.

Bagi ujian-t tidak bersandar yang pertama, skor min ujian pra kesemua sampel bagi kedua-dua kumpulan telah dijadikan asas untuk memastikan kedua-dua kumpulan adalah homogen, seperti ditunjukkan pada Jadual 2.

Jadual 2 Perbandingan Ujian Pra Kumpulan Kaedah PBPj dan Kaedah PT

\begin{tabular}{ccccccc}
\hline Kaedah & $\mathrm{N}$ & Min & Sisihan piawai & $\begin{array}{c}\text { Darjah } \\
\text { kebebasan }\end{array}$ & Nilai t & Signifikan \\
\hline PBPJ & 30 & 43.50 & 10.35 & 58 & -.61 & .37 \\
PT & 30 & 45.00 & 8.61 & & & \\
\hline
\end{tabular}

Keputusan ujian-t pada Jadual 2 menunjukkan tidak terdapat perbezaan yang signifikan bagi pencapaian akademik sampel antara kumpulan kaedah PBPj dan kaedah PT berdasarkan nilai t (58) = -.61, p<.05. Ini bermakna kedua-dua kumpulan kaedah PBPj dan kaedah PT mempunyai pencapaian akademik awal yang setara sebelum kajian dimulakan. Skor min menunjukkan tidak terdapat perbezaan yang signifikan bagi sampel yang berada dalam kumpulan kaedah PBPj dengan sampel yang berada dalam kumpulan kaedah PT. Maka, hipotesis nul diterima.

Melalui bacaan Levene Test skor ujian pra kedua-dua kumpulan, didapati bahawa nilai $\mathrm{F}(.80)=.37$, p<.05. Ini bermakna varian kedua-dua kumpulan adalah sama iaitu kesemua sampel dari kumpulan kawalan dan rawatan adalah daripada populasi yang setara. Berdasarkan bacaan perbezaan skor min 1.50, maka tidak terdapat perbezaan skor sampel antara kedua-dua kumpulan kajian. Selain skor 
ujian pra, skor yang diperoleh dari peperiksaan pertengahan tahun mata pelajaran Biologi kesemua sampel yang terlibat juga dijadikan asas untuk memastikan kedua-dua kumpulan adalah homogen, seperti pada Jadual 3.

Jadual 3 Perbandingan Markah Peperiksaan Pertengahan Tahun Kumpulan Kaedah PBPj dan Kaedah PT

\begin{tabular}{|c|c|c|c|c|c|c|}
\hline Kaedah & $\mathrm{N}$ & $\overline{M i n}$ & Sisihan piawai & $\begin{array}{c}\text { Darjah } \\
\text { kebebasan }\end{array}$ & Nilai t & Signifikan \\
\hline PBPj & 30 & 57.70 & 10.06 & 58 & -.68 & .26 \\
\hline PT & 30 & 59.73 & 12.87 & & & \\
\hline
\end{tabular}

Keputusan ujian-t pada Jadual 3 menunjukkan tidak terdapat perbezaan yang signifikan bagi pencapaian akademik sampel antara kumpulan kaedah PBPj dan kaedah PT berdasarkan nilai t (58) =-.68, p <.05. Ini bermakna kedua-dua kumpulan kawalan dan rawatan adalah setara dari segi pencapaian akademik sebelum kajian dimulakan. Skor min menunjukkan tidak terdapat perbezaan yang signifikan bagi sampel yang berada dalam kumpulan kaedah PBPj dengan sampel yang berada dalam kumpulan kaedah PT.

Melalui bacaan Levene Test juga, didapati bahawa skor ujian pra kedua-dua kumpulan mempunyai nilai $\mathrm{F}(1.27)=.26$, p<.05. Ini bermakna varian kedua-dua kumpulan adalah sama iaitu kesemua sampel dari kumpulan kawalan dan rawatan adalah daripada populasi yang setara. Berdasarkan bacaan perbezaan skor min 2.03, maka tidak terdapat perbezaan skor sampel antara kedua-dua kumpulan kajian. Berdasarkan sifat homogen kedua-dua kumpulan yang telah dibuktikan melalui analisis data ujian pra dan peperiksaan pertengahan tahun sampel bagi kedua-dua kumpulan, maka ujian-ujian yang berkaitan telah dijalankan untuk menguji hipotesis-hipotesis kajian yang lain.

Perbandingan Skor Min Ujian Pra dan Pasca Kumpulan Pembelajaran Berasaskan Projek

Perbandingan secara statistik dilakukan untuk mengenal pasti sejauh mana jenis $\mathrm{P}$ dan $\mathrm{P}$ yang diberikan memberi kesan yang signifikan kepada pencapaian akademik sampel mengikut kumpulan masing-masing. Bagi kumpulan yang pertama iaitu kumpulan kaedah PBPj, hipotesis kajian yang kedua dan keputusan ujian-t berpasangan adalah seperti pada Jadual 4.

Ho2: $\quad$ Tidak terdapat perbezaan yang signifikan bagi skor min ujian pra dan ujian pasca kumpulan kaedah PBPj.

Jadual 4 Perbandingan ujian pra dan ujian pasca sampel kumpulan kaedah PBPj

\begin{tabular}{llccccc}
\hline Ujian & $\mathrm{N}$ & Min & Sisihan piawai & $\begin{array}{c}\text { Darjah } \\
\text { kebebasan }\end{array}$ & Nilai t & Signifikan \\
\hline Pra & 30 & 63.33 & 8.61 & 29 & 10.47 & .00 \\
Pasca & 30 & 45.00 & 10.53 & & & \\
\hline
\end{tabular}

Ujian-t berpasangan yang digunakan untuk menentukan perbezaan antara ujian pra dan ujian pasca bagi DK menunjukkan terdapat perbezaan yang signifikan antara pencapaian akademik sampel kumpulan kaedah PBPj dalam ujian pra dibandingkan dengan ujian pasca berdasarkan nilai $\mathrm{t}(29)=10.47, \mathrm{p}<.05$. Ini bermakna skor min menunjukkan terdapat perbezaan yang signifikan bagi markah sampel yang menduduki ujian pra sebelum didedahkan dengan topik 'Ekosistem Terancam' dengan markah mereka dalam ujian pasca selepas pengajaran kaedah PBPj dilakukan. Maka, hipotesis nul berjaya ditolak.

\section{Perbandingan Skor Min Ujian Pra dan Pasca bagi Kumpulan Pengajaran Tradisional}

Bagi kumpulan yang kedua iaitu sampel kumpulan kawalan, keputusan ujian-t berpasangan adalah seperti pada Jadual 5. Seperti sampel kumpulan kaedah PBPj, sampel kumpulan kaedah PT turut menjalani ujian pra sebelum kajian dan ujian pasca selepas habis tempoh kajian. Hipotesis kajian yang ketiga dinyatakan seperti berikut:

$\mathrm{H}_{0} 3$ : Tidak terdapat perbezaan yang signifikan bagi skor min ujian pra dan ujian pasca bagi kumpulan kaedah PT.

Jadual 5 Perbandingan ujian pra dan ujian pasca sampel kumpulan kaedah PT

\begin{tabular}{|c|c|c|c|c|c|c|}
\hline Ujian & $\mathrm{N}$ & Min & Sisihan piawai & Darjah kebebasan & Nilai t & Signifikan \\
\hline Pra & 30 & 43.50 & 10.36 & 29 & 11.09 & .05 \\
\hline Pasca & 30 & 71.33 & 13.58 & & & \\
\hline
\end{tabular}

Ujian-t berpasangan yang digunakan untuk menentukan perbezaan antara ujian pra dan ujian pasca bagi DK menunjukkan terdapat perbezaan yang signifikan antara pencapaian akademik sampel dalam ujian pra dibandingkan dengan ujian pasca berdasarkan nilai t (29) $=11.09, \mathrm{p}<.05$. Ini bermakna skor min menunjukkan terdapat perbezaan yang signifikan bagi skor sampel yang menduduki ujian pra sebelum didedahkan dengan topik Ekosistem Terancam dengan skor mereka dalam ujian pasca selepas P dan P menggunakan kaedah PT dilakukan. Maka, hipotesis nul berjaya ditolak. 


\section{Perbandingan Skor Min Ujian Pasca Kumpulan Kaedah Pembelajaran Berasaskan Projek dan Pembelajaran Tradisional}

Perbandingan seterusnya adalah untuk membandingkan skor min ujian pasca bagi sampel kumpulan kaedah PBPj dan sampel bagi kumpulan kaedah PT. Rajah 6 menunjukkan perbandingan skor min ujian pra dan ujian pasca bagi kedua-dua kumpulan.

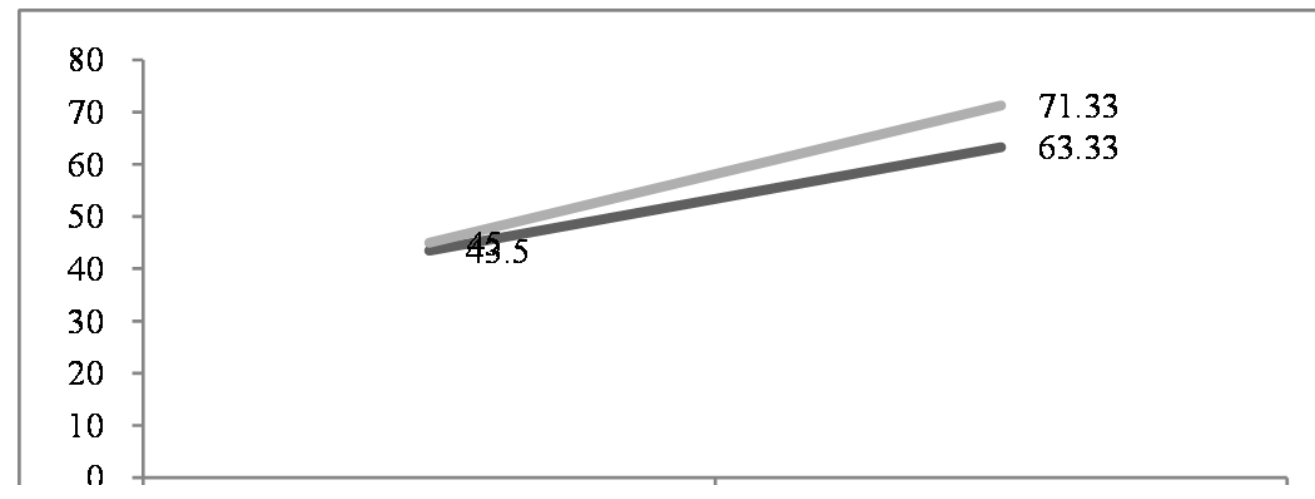

Rajah 6 Perbandingan skor min ujian pra dan ujian pasca kumpulan kaedah PBPJ dan Kaedah PT

Secara deskriptif didapati bahawa min ujian pra bagi sampel kumpulan kaedah PT (45.00) adalah lebih tinggi berbanding min ujian pra sampel kumpulan kaedah PBPj (43.50) dengan perbezaan skor min sebanyak 1.50. Walaupun kedua-dua kumpulan menunjukkan peningkatan skor dalam ujian pasca, skor min bagi kumpulan kaedah PT masih mendahului (71.33) jika dibandingkan dengan skor min kumpulan kaedah PBPj (63.33) dengan perbezaan skor sebanyak 8.00. Perbandingan skor min kedua-dua ujian pra dan pasca menunjukkan sampel dalam kumpulan kaedah PT menunjukkan peningkatan skor sebanyak 26.33 manakala sampel dalam kumpulan kaedah PBPj menunjukkan peningkatan skor lebih rendah iaitu sebanyak 19.83 .

Hipotesis kajian yang seterusnya adalah membandingkan kesan kaedah PBPj dan kaedah PT terhadap pencapaian akademik sampel melalui ujian pasca. Jadual 8 menunjukkan perbandingan kesan kaedah PBPj dan kaedah PT seperti yang dinyatakan. Hipotesis yang keempat terhadap pencapaian akademik yang dinyatakan sebagai:

H04: Tidak terdapat perbezaan yang signifikan bagi skor min ujian pasca antara kumpulan kaedah PBPj dan kumpulan kaedah PT.

Jadual 6 Perbandingan ujian pasca kumpulan kaedah PBPj dan Kaedah PT

\begin{tabular}{|c|c|c|c|c|c|c|}
\hline Kaedah & $\mathrm{N}$ & Min & Sisihan piawai & $\begin{array}{c}\text { Darjah } \\
\text { kebebasan }\end{array}$ & Nilai t & Signifikan \\
\hline$\overline{\mathrm{PBPj}}$ & 30 & 63.33 & 10.53 & 58 & 2.56 & .10 \\
\hline PT & 30 & 71.33 & 13.58 & & & \\
\hline
\end{tabular}

Dapatan kajian berdasarkan Jadual 6 menunjukkan perbezaan skor min ujian pasca bagi pencapaian akademik sampel kumpulan kaedah PBPj adalah tidak berbeza secara signifikan berbanding sampel dalam kumpulan kaedah PT. Keputusan ujian-t menunjukkan tidak terdapat perbezaan yang signifikan dalam DK antara sampel dalam kumpulan kaedah PBPj dengan sampel dalam kumpulan kaedah PT berdasarkan nilai $\mathrm{t}(58)=2.56, \mathrm{p}<.05$. Ini bermakna hipotesis nul diterima, skor min menunjukkan tidak terdapat perbezaan yang signifikan bagi pencapaian akademik sampel yang menggunakan kaedah PBPj dengan sampel yang menggunakan kaedah PT untuk ujian pasca.

\subsection{PERBINCANGAN}

\section{Kesan Pelaksanaan PBH melalui Kaedah PBPj dan PT terhadap Pencapaian Akademik}

Perbandingan ujian pra kedua-dua kumpulan kaedah PBPj dan kaedah PT mendapati bahawa tidak terdapat perbezaan yang signifikan. Ini menunjukkan kesemua sampel dalam kumpulan-kumpulan tersebut mempunyai tahap pemahaman yang setara sebelum kajian dimulakan. Salah satu sebab utama yang menyumbang kepada dapatan ini adalah kerana topik Ekosistem Terancam merupakan topik yang terakhir dalam sukatan pelajaran dan masih belum dipelajari oleh seorang pun daripada mereka. Mereka juga mempunyai pengetahuan sedia ada yang setara antara satu sama lain.Oleh sebab itu segala jawapan yang diberikan dalam ujian pra hanya bergantung kepada pengetahuan sedia ada dan pemahaman mereka tentang konsep ekosistem terancam melalui apa yang telah dipelajari sebelum ini.

Selain ujian pra, gred mata pelajaran Biologi bagi peperiksaan pertengahan tahun, gred mata pelajaran Sains dalam PMR menunjukkan tahap pemahaman mereka yang tidak berbeza secara signifikan walaupun ditempatkan dalam dua kumpulan berbeza. Komposisi sampel bagi kedua-dua kumpulan yang homogen membuktikan bahawa pemahaman mereka adalah setara sebelum kajian dimulakan. 
Hipotesis seterusnya menunjukkan perbandingan antara skor min ujian pra dan ujian pasca sampel kumpulan kaedah PBPj. Hasil analisis statistik yang signifikan menunjukkan penerapan kaedah PBPj didapati telah meningkatkan kefahaman sampel kajian terhadap topik Ekosistem Terancam. Walaupun skor min yang diperoleh adalah lebih rendah berbanding sampel kumpulan kaedah PT, peningkatan ini membuktikan kaedah PBPj masih dianggap relevan untuk digunakan dalam P dan P khususnya bagi topik ini. Aplikasi kaedah PBP dengan cara menghasilkan artifak membolehkan sampel menginterpretasikan kefahaman mereka dalam bentuk yang lain dari kelaziman. Sampel diberi ruang dan masa yang tersendiri untuk mengumpul maklumat tanpa perlu mengharapkan guru sebagai sumber utama yang mengajar mereka untuk topik ini.

Apabila perbandingan dibuat antara skor ujian pra dan ujian pasca bagi sampel dalam kumpulan kaedah PT, perbezaan yang signifikan juga diperoleh. Walaupun kaedah PBPj diperkenalkan kepada pelajar kumpulan rawatan, sampel kumpulan kawalan dilihat mampu menyaingi rakan mereka dengan hanya belajar menggunakan kaedah pembelajaran secara tradisional iaitu berpusatkan guru. Sampel dalam kumpulan kaedah PT tetap mampu menguasai topik Ekosistem Terancam tanpa perlu melalui proses perbincangan, pembentangan dan menghasilkan artifak seperti brosur dan poster seperti yang dilakukan oleh sampel dalam kumpulan kaedah PBPj. Ini menunjukkan bahawa kaedah PT masih kekal relevan untuk digunakan dalam sesi P dan P bagi topik yang dinyatakan.

Dapatan kajian yang seterusnya menunjukkan perbandingan keputusan pencapaian akademik ujian pasca antara dua kumpulan kaedah PT dan PBPj yang tidak signifikan. Sampel kumpulan kaedah PBPj dilihat mampu mencari maklumat yang sesuai dengan tahap pemahamannya, dan tidak lagi bergantung sepenuhnya pada guru sebagai sumber maklumat utama. Pemahaman sampel dalam kedua-dua kumpulan didapati setara selepas lima minggu kajian dijalankan. Dapatan kajian ini yang menunjukkan kelebihan penggunaan kaedah PBPj seperti yang turut dilaporkan dalam kajian-kajian sebelum ini yang mana topik Ekosistem Terancam boleh dikuasai oleh sampel tanpa memerlukan guru berada bersama-sama sepanjang masa. Walau bagaimanapun dapatan kajian ini tidak menyokong dapatan kajiankajian lepas berkaitan peningkatan pencapaian akademik sampel kajian (Yamzon, 1999; Turner \& Grizzaffi, 2003; Brodi, 2008; Yalcin et al., 2009; Bas, 2010; Bell, 2010; Kamaruzaman \& Khairul, 2010; Kaldi et al., 2011) tetapi selari dengan dapatan kajian oleh Chang \& Tseng (2011).

Implikasi dapatan kajian tentang pencapaian akademik pelajar menunjukkan walaupun kaedah PBPj diperkenalkan hanya kepada sampel kumpulan rawatan, tetapi sampel kumpulan kawalan dilihat mampu menyaingi rakan mereka yang belajar menggunakan kaedah pembelajaran yang berbeza dari kelaziman. Sampel dalam kumpulan kaedah PT tetap mampu menguasai topik Ekosistem Terancam tanpa perlu melalui proses perbincangan, pembentangan dan menghasilkan artifak seperti brosur dan poster seperti yang dilakukan oleh sampel dalam kumpulan kaedah PBPj. Namun begitu, sampel dalam kumpulan kaedah PBPj mampu menguasai topik yang dipelajari tanpa perlu belajar berpusatkan guru. Selain daripada itu, pelajar kumpulan rawatan mampu menyesuaikan diri mereka dengan kaedah PBPj yang diperkenalkan dan menunjukkan pencapaian ilmu konten yang setara jika dibandingkan dengan rakan mereka dalam kumpulan kaedah PT. Ini menunjukkan sampel kumpulan kaedah PBPj mampu mengurus pembelajaran mereka sendiri dan menggunakan kaedah pembelajaran kendiri walaupun hanya dengan bantuan rakan-rakan.

Secara keseluruhannya, dapatan kajian ini secara tidak langsung menolak kajian oleh Mona \& Maizurah (2002) yang menyatakan peranan guru sebagai konstruktif masih di peringkat rendah, dan pola P dan P masih tetap berpusatkan guru. Penerapan kaedah PBPj yang memerlukan sampel kajian bersikap lebih berdikari dengan mencari maklumat dan memahami konsep melalui artifak yang dihasilkan dilihat berjaya. Peranan guru sebagai fasilitator mampu mengubah kebiasaan sampel yang sekian lama terbiasa dengan kaedah $\mathrm{P}$ dan $\mathrm{P}$ secara berpusatkan guru dan perkara ini sepatutnya dijadikan sebagai amalan guru di sekolah. Peranan guru pada masa kini seharusnya berubah seiring dengan perkembangan semasa dan murid-murid sepatutnya diberi lebih kebebasan untuk menentukan kaedah pembelajaran yang lebih sesuai dengan mereka.

Kebergantungan penilaian berdasarkan pencapaian akademik semata-mata telah menafikan peluang pelajar ini untuk menunjukkan dimensi lain dalam diri mereka. Penilaian secara holistik memberi dimensi baharu kepada pelajar untuk dinilai secara menyeluruh berdasarkan Huraian Pelajaran yang telah digariskan, dan penilaian itu dilakukan dari setiap domain yang sepatutnya iaitu DK, DA dan DP. Ini selari dengan apa yang diperkatakan oleh Thompson \& Mintzes (2002) bahawa kecenderungan seseorang pelajar untuk mempunyai sikap yang dinilai sama ada disukai atau tidak dipengaruhi oleh komponen DK, DA dan tingkah lakunya iaitu melalui domain psikomotor (DP). Maka, berdasarkan kelebihan yang ada pada penilaian melalui kaedah PBH, ia patut diaplikasikan dengan lebih meluas kepada pelajar sekolah.

\subsection{KESIMPULAN DAN IMPLIKASI KAJIAN}

Kesimpulannya, Pendidikan Berasaskan Hasil (PBH) memberikan peluang untuk pelajar mempamerkan pencapaian dalam domain kognitif yang setara walaupun pelbagai kaedah pengajaran dan pembelajaran digunakan dalam bilik darjah. Implikasi kajian ini menunjukkan kurikulum yang digubal oleh Bahagian Pembangunan Kurikulum, KPM boleh menilai domain kognitif secara homogenous yang dilaksanakan dalam PBH dengan kepelbagaian strategi pembelajaran dan pengajaran yang dilaksanakan. Kajian lanjutan yang boleh dijalankan ialah mengenal pasti implikasi pelaksanaan PBH kepada pencapaian pelajar dalam domain afektif dan psikomotor dengan membandingkan pelaksanaan beberapa kaedah pembelajaran. Seterusnya, penilaian melalui kaedah PBH yang menggabungkan pencapaian pelajar dalam ketiga-tiga domain pembelajaran juga satu aspek yang boleh diterokai untuk menghasilkan gred prestasi holistik pelajar.

\section{Rujukan}

Anderson, L. W., \& Krathwohl, D. R. (2001). A Taxonomy for Learning, Teaching and Assessing: A Revision of Bloom's Taxonomy of Educational Objectives. New York: Longman.

Bahagian Teknologi Pendidikan. (2006). Project Based Learning Handbook. Kuala Lumpur. Bahagian Teknologi Pendidikan.

Bas, G. (2010). Effects of Multiple Intelligences Supported Project-Based Learning on Students' Achievement Levels and Attitude Towards English Lesson. International Electronic Journal of Elementary Education, 2(3), 365-385.

Bell, S. (2010). Project Based Learning for the 21st Century: Skills for the Future. The Clearing House: Journal of Educational Strategies, Issues and Ideas, 83(2), 3943. 
Biggs, J.B. (2003). Teaching for Quality Learning At University. (Edisi Kedua). Buckingham: Open University Press/Society for Research into Higher Education. Bloom, B. S. (1956). Taxonomy of Educational Objectives, Handbook I: The Cognitive Domain. New York: David McKay Co. Inc.

Blumenfeld, P. C., Soloway, E., Marx, R. W., Krajcik, J. S., Guzdial, M., \& Palincsar, A. (1991). Motivating Project-Based Learning: Sustaining the Doing, Supporting the Learning. Educational Psychologist, 26(3\&4), 369-398.

Brodi, J. (2008). Pelaksanaan Pembelajaran Berasaskan Projek: Satu Kajian Kes Teaching School, IPTAR. Jurnal Penvelidikan Pendidikan IPTAR, 99-119.

Butler, M. (2004). Outcome Based/ Outcomes Focused Education Overview. (Manuskrip tidak diterbitkan). Fakulti Pendidikan Universiti Newcastle, Australia.

Chan Lin, Lih-Juan. (2008). 'Technology Integration Applied to Project-based Learning in Science'. Innovations in Education and Teaching International, 45(1), 5565.

Chang, Chi-Cheng., \& Tseng, Kuo-Hung. (2011). Using a Web-based Portfolio Assessment System to Elevate Project Based Learning Performances. Interactive Learning Environment, 19(3), 211-230.

Chin, C., \& Chia, Li-Gek. (2006). Problem-Based Learning: Using Ill-Structured Problems in Biology Project Work. Science Education, 90(1), 44-67.

Christidou, V. (2006). Greek Students' Science-related Interests and Experiences: Gender Differences and Correlations. International Journal of Science Education, $28(10), 1181-1199$.

Cohen, L., Manion, L., \& Morrison, K. (2001). Research Methods in Education. (Edisi Kelima). London: RoutledgeFalmer.

Cook, T. D., \& Campbell, D. T. (2006). The Causal Assumptions of Quasi-Experimental Practice: The Origins of Quasi-Experimental Practice. Dalam David de Vaus. Editor (Ed.), Research Design. (Volume II). London: SAGE Publications Ltd.

Felder, R. M., \& Soloman, B. A. (1993). Learning and Teaching Styles in Engineering Education. Engineering Education, 78(7), 674-681.

Fraenkel, J. R., \& Wallen, N. E. (1996). How to Design and Evaluate Research in Education. Amerika Syarikat: McGraw-Hill.

Harrrow, A. J. (1972). A Taxonomy of the Psychomotor Domain. New York: David McKay Co.

Jaafar, M. S., Nordin, N. K., Wagiran, R., Aziz, A., Noor, M. J. M. M., Osman, M. R., Noorzaei, J., \& Abdulaziz, F. N. A. (2008). Assessment Strategy for an Outcome Based Education. Education, 1-8.

Kaldi, S. Filippatou, D., \& Govaris, C. (2011). Project-Based Learning in Primary Schools: Effects on Pupils' Learning and Studies. Education, 39(1), 35-47.

Kamaruzaman Jusoff \& Khairul Azhar Mat Daud. (2010). Motivating Students Using Project Based Learning (PjBL) via e-SOLMS Technology. World Applied Science Journal, 8(9), 1086-1092.

Kementerian Pendidikan Malaysia, (2015). Pelan Pembangunan Pendidikan Malaysia 2015-2025 (Pendidikan Tinggi). Putrajaya: KPM.

Killen, R. (2000). Outcomes-based education: Principles and Possibilities. (Manuskrip Tidak Diterbitkan). Fakulti Pendidikan, University of Newcastle.

Martin, D. W. (2008). Doing Psychology Experiments (Edisi Ketujuh). California: Thomson Wadsworth.

Md. Baharuddin Abdul Rahman, Hairul Nizam Ismail, Khairul Azhar Mat Daud \& Mohd Ariff Ibrahim. (2011). The Outcome Based Education (OBE) at Politeknik Kota Bharu, Malaysia. International Journal of Humanities and Social Science, 1(8). 163-171

Miller, P. H., Blessing, J. S., \& Schwartz, S. (2006). Gender Differences in High-school Students' Views About Science. International Journal of Science Education, 28(4), 363-381.

Mohd Ghazali Mohayidin, Turiman Suandi, Ghazali Mustapha, Mohd. Majid Konting, Norfaryanti Kamaruddin, Nor Azirawani Man, Azura Adam \& Siti Norziah Abdullah. (2008). Implementation of Outcome-Based Education in University Putra Malaysia: A Focus on Students' Learning Outcomes. International Education Studies Journal, 1(4), 147-160.

Mohd Zuri Ghani, Aznan Che Ahmad \& Nurul Husna Mat Husin. (n.d.). Sikap Rakan Sebaya Dalam Kalangan Pelajar Pintar Cerdas Akademik. Dimuat turun daripada laman sesawang: http://education.usm.my/images/docs/MEDC/VOL8/sikap\%20rakan\%20sebaya\%20di\%20kalangan\%20pelajar \%20pintar\%20cerdas\%20akademikmedc-2.pdf. 6 Februari, 2017.

Mohd Zuri Ghani, Nik Rusila Nik Yaacob, Aznan Che Ahmad, Rahimi Che Aman \& Zainuddin Mat Isa. (2010). Perbezaan personaliti kestabilan emosi dalam kalangan pelajar pintar cerdas akademik (PCA) berdasrkan jantina dan jenis sekolah. Asia Pacific Journal of Educator and Education, 25, 153-167.

Mona Masood \& Maizurah Omar. (2002). Pendekatan Konstruktivis: Realiti di Bilik Darjah. Pembentangan Kertas Kerja di Konvensyen Teknologi Pendidikan ke-15, Perlis, 6-9 September 2002.

Mookdaporn Panasan \& Prasat Nuangchalerm. (2010). Learning Outcomes of Project-Based and Inquiry-Based Learning Activities. Journal of Social Sciences, 6(2), $252-255$

Noraini Idris. (2010). Penyelidikan dalam Pendidikan. Malaysia: McGraw-Hill.

Pallant, J. (2005). SPSS Survival Manual (Edisi Kedua). New South Wales, Australia: Alex \& Unwin.

Papanikolaou, K., \& Boubouka, M. (2010). Promoting Collaboration in a Project-Based E-Learning Context. Journal of Research on Technology in Education, 43(2), $135-155$

Plutchik, R. (1983). Foundations of Experimental Research (Edisi ketiga). New York: Harper \& Row Publishers, Inc.

Pusat Perkembangan Kurikulum. (2006). Sukatan Pelajaran Biologi. Kuala Lumpur: Pusat Perkembangan Kurikulum.

Rosadah Abd Majid, Noriah Mohd Ishak \& Zalizan Mohd Jelas. (2005). Profil Pemprosesan Kognitif Pelajar Pintar Cerdas Akademik Di Sekolah Menengah. Jurnal Pendidikan, 30, 35-49.

Roslan Hashim \& Mokhtar Azizi Mohd Din. (2009). Implementing Outcome Based Education Using Project Based Learning at University of Malaya. European Journal of Scientific Research, 26(1), 80-86.

Siti Fatimah Mohd Yassin, Baharuddin Aris \& Abdul Hafidz Omar. (2006). Strategi Pembelajaran Projek Pembangunan Produk Multimedia Kreatif Secara Kolaboratif. Jurnal Pendidikan Universiti Teknologi Malaysia, 11, 24-35.

Spady, W. G. (1994). Outcome-Based Education: Critical Issues and Answers. Arlington: American Association of School Administrators.

Thompson, T. L., \& Mintzes, J. J. (2002). Cognitive Structure and the Affective Domain: On Knowing and Feeling in Biology. International Journal of Science Education, 24(6), 645-660.

Turner, R. M., \& Grizzaffi, K. (2003). Creative Learning for Service Learning: A Project-Based Approach. Kertas Kerja dibentangkan di Annual Meeting of the Campus Compact National Center for Community Colleges, 12 ${ }^{\text {th }}$, Scottsdale, AZ, 21-23 Mei 2003.

Vygotsky, L. S. (1978). Interaction Between Learning And Development. From: Mind And Society: The Development Of Higher Mental Process. Cambridge: MA: Harvard University Press.

Yalcin, S. A., Turgut, U., \& Buyukkasai, E. (2009). The Effect of Project Based Learning on Science Undergraduates' Learning of Electricity, Attitude towards Physics and Scientific Process Skills. International Online Journal of Education Sciences, 1(1), 81-105.

Yamzon, A. (1999). An Examniation of the Relationship between Student Choice in Project-Based Learning and Achievement. Dimuat turun pada 2 Februari 2011 dari http://www.eric.ed.gov/PDFS/ED430940.pdf

Zimmerman, D. C. (2010). Project Based Learning for Life Skill Building in $12^{\text {th }}$ Grade Social Studies Classrooms: A Case Study. (Tesis Sarjana. Tidak Diterbitkan). Universiti Dominican California, San Rafael, CA. 